\title{
Fungal communities on speleothem surfaces in Kartchner Caverns, Arizona, USA.
}

\author{
Michael J. Vaughan ${ }^{1}$, Raina M. Maier ${ }^{2}$, and Barry M. Pryor ${ }^{1^{*}}$
}

\begin{abstract}
:
Vaughan M.J., Maier R.M., Pryor B.M. 2011. Fungal communities on speleothem surfaces in Kartchner Caverns, Arizona, USA. International Journal of Speleology, 40(1), 65-77. Tampa, FL (USA). ISSN 0392-6672. DOI: 10.5038/1827-806X.40.1.8

Kartchner Caverns, located near Benson, Arizona, USA, is an active carbonate cave that serves as the major attraction for Kartchner Caverns State Park. Low-impact development and maintenance have preserved prediscovery macroscopic cavern features and minimized disturbances to biological communities within the cave. The goal of this study was to examine fungal diversity in Kartchner Caverns on actively-forming speleothem surfaces. Fifteen formations were sampled from five sites across the cave. Richness was assessed using standard culture-based fungal isolation techniques. A culture-independent analysis using denaturing gradient gel electrophoresis (DGGE) was used to assay evidence of community homogeneity across the cave through the separation of $18 \mathrm{~S}$ rDNA amplicons from speleothem community DNA. The culturing effort recovered 53 distinct morphological taxonomic units (MTUs), corresponding to 43 genetic taxonomic units (GTUs) that represented 21 genera. From the observed MTU accumulation curve and the projected total MTU richness curve, it is estimated that 51 percent of the actual MTU richness was recovered. The most commonly isolated fungi belonged to the genera Penicillium, Paecilomyces, Phialophora, and Aspergillus. This culture-based analysis did not reveal significant differences in fungal richness or number of fungi recovered across sites. Cluster analysis using DGGE band profiles did not reveal distinctive groupings of speleothems by sample site. However, canonical correspondence analysis (CCA) of cultureindependent DGGE profiles showed a significant effect of sampling site and formation type on fungal community structure. Taken together, these results reveal that diverse fungal communities exist on speleothem surfaces in Kartchner Caverns, and that these communities are not uniformly distributed spatially. Analysis of sample saturation indicated that more sampling depth is required to uncover the full scale of mycological richness across spelothem surfaces.
\end{abstract}

Keywords: fungal community, DGGE, USA, Arizona, Kartchner Caverns

Received 17 October 2010; Revised 30 November 2010; Accepted 24 December 2010

\section{INTRODUCTION}

Kartchner Caverns, located in Benson, Arizona, USA (N31 $\left.50^{\prime} 08^{\prime \prime}, \mathrm{W} 110^{\circ} 20^{\prime} 37^{\prime \prime}\right)$, is a wet, actively forming carbonate cave in the Whetstone Mountains. First discovered in 1974, the cave was kept a closely guarded secret among the cave's discoverers in an effort to preserve the cave from anthropogenic harm. In 1988, the State of Arizona purchased the land surrounding the cave and began development of Kartchner Caverns State Park (Tufts \& Tenen, 1999). Special effort was made during the development process to preserve the pristine status of the cave while making portions of it accessible to tourism. In

\footnotetext{
${ }^{1}$ School of Plant Sciences, Div. of Plant Pathology, University of Arizona, Tucson, Arizona, USA 85719

E-mail: mvaughan@email.arizona.edu

2 Department of Soil, Water, and Environmental Sciences, University of Arizona, Tucson, Arizona, USA 85719

E-mail: rmaier@Ag.arizona.edu

* Corresponding author - Mail: Forbes Building, Room 303; 1140 E. South Campus Dr.; P.O. Box 210036; Tucson, AZ 85721. Tel: 520-626-2781. E-mail: bmpryor@u.arizona.edu
}

the process of sustainably developing the cave, indepth studies were conducted to unravel its hydrology (Garf, 1999), mineralogy (Hill, 1999), microclimates (Buecher, 1999), biology (Buecher \& Sidner, 1999; Welbourn, 1999), and yearly environmental cycles. As a result, Kartchner Caverns is among the most comprehensively studied carbonate caves in the world.

Kartchner Caverns is also listed as one of the top ten caves in terms of mineralogical diversity (Hill \& Forti, 1997). Its mineral diversity, protected status, well studied environmental conditions, and its plethora of carbonate formations make this $3.9 \mathrm{~km}$ long cave an excellent site to explore microbial communities associated with the subterranean environment. Consequently, in 2006, Kartchner Caverns was added to the National Science Foundation's list of Microbial Observatories (MO). The goal of the Kartchner Caverns MO is to characterize microbial communities living within the caverns in order to better understand (1) how life exists in this light-deprived oligotrophic 
Fig.1. Map of Kartchner Caverns showing the location on the five sampling

sites. Three speleothems at each site were selected for sampling.

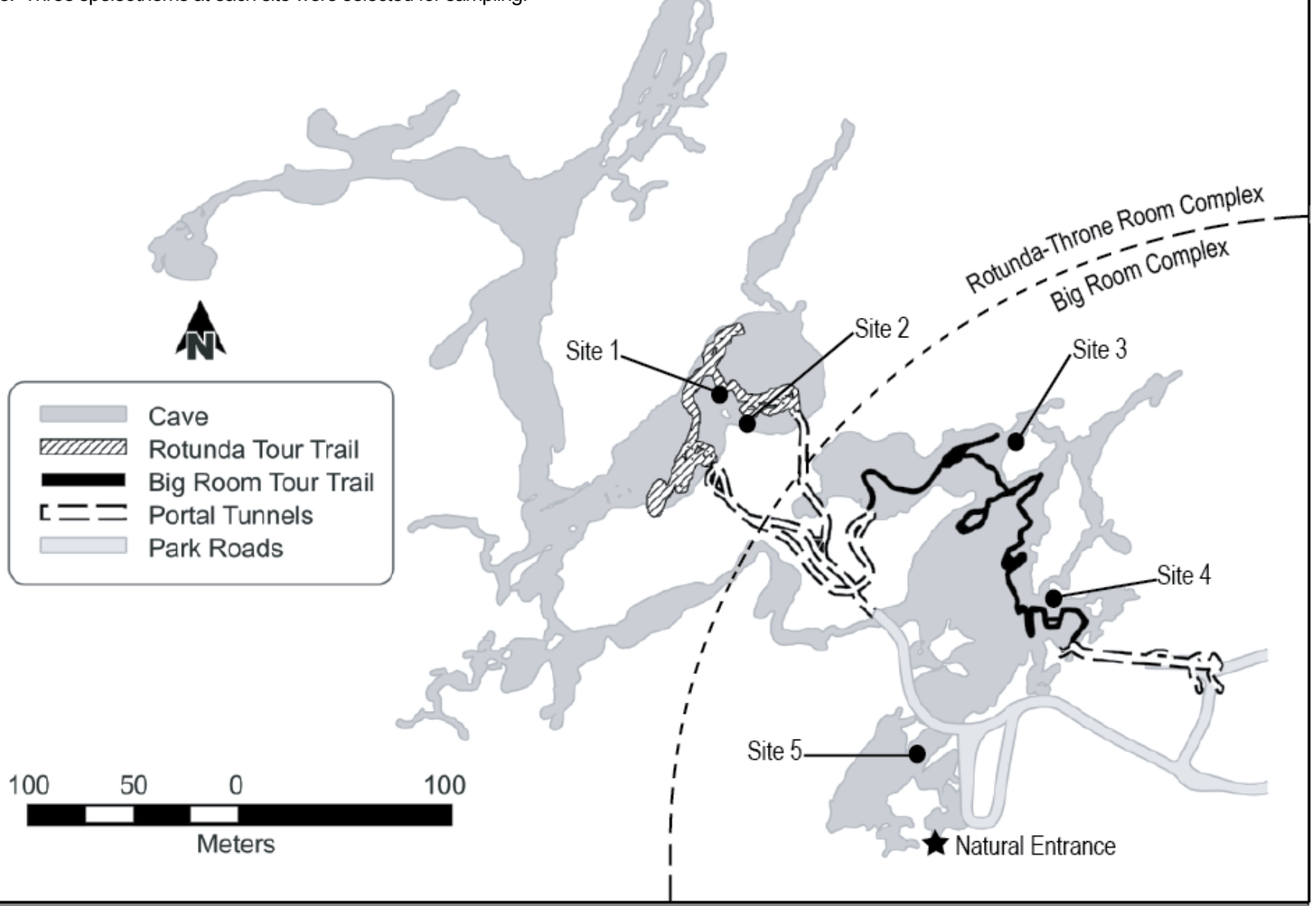

environment with respect to community construction and (2) how these microbial communities might influence speleothem development. Biospeleogenetic processes carried out by microbial communities living on mineral surfaces is an area of intense interest to speleologists (Barton \& Northup, 2007). Evidence for biospeleogenetic effects on speleothem development have been documented in studies in Lechuguilla Cave in New Mexico and other cave systems (Davis et al., 1990; Cunningham et al., 1995; Cañaveras et al., 2005). Yet, these and most other studies of cave microbes focus almost exclusively on the prokaryotic communities on cave formations and mineral surfaces (Ikner et al., 2007; Barton \& Northup, 2007; Jones et al., 2008, Cuezva, 2009). A notable exception are the studies by Novakova (2009) in the Domica cave system in Slovakia that explicitly looked for the presence of microfungi on speleothem surfaces and cited their possible role in vermiculation development (Camassa \& Febroriello, 2003). Other cave fungal surveys have been conducted, but most are restricted to looking for fungi pathogenic to humans or other macrofauna (Ajello et al., 1960; Lyon et al., 2004), thermophilic fungi (Nagai et al., 1998; Hsu \& Agoramoorthy, 2001), fungus-like organisms (Landolt et al., 2006), or non-speleothem substrates (Orpurthe, 1964; Reeves et al., 2000, Bastian \& Alabouvette, 2009). Given the interest in how biospeleogenetic processes might affect cave formations, it is interesting that fungal communities in karst systems are not studied more intensely (Gadd, 2004; Engel, 2007).
Fungi are known to grow on and alter mineral surfaces and to play important roles in rock surface communities (Burford et al., 2003a; Gorbushina, 2007). It is widely accepted that these fungi are essential in the biological weathering of mineral substrates through physical separation of particles and the activity of excreted secondary metabolites and organic acids (Hoppert et al., 2004). These metabolites weather the substrate by changing the $\mathrm{pH}$ of the microenvironment or changing the energy states of ions in the rock matrix at its surface (Ehrlich, 1998; Gadd \& Sayer, 2000). In the process of rock dissolution, the fungi also provide suitable physical environments and mobilize nutrients for other microbes that inhabit mineral substrates (Gadd \& Sayer, 2000).

Preliminary studies of fungal communities in Kartchner Caverns from different substrates using culture-based techniques revealed low fungal richness on mineral substrates as compared to cave sediments and guano piles (Vaughan et al., 2008). These studies also revealed the same fungi were found on all of the mineral surfaces sampled suggesting homogeneity in distribution. The objective of this study was to further explore fungi communities in Kartchner Caverns using both culture-based and non-culturebased techniques, with a focus specifically on speleothem surfaces. Fungal richness was assessed across a number of carbonate formations based upon recovered culturable fungi, and the herterogeneity 
of fungal communities was assessed based upon denaturing gradient gel electrophoresis (DGGE) analysis of $18 \mathrm{~S}$ rRNA gene amplicons from community DNA. These data will contribute to on-going efforts to fully characterize fungal communities across varied substrates in Kartchner Caverns and explore their roles in subterranean ecology and biospeleogenesis.

\section{MATERIALS AND METHODS}

\section{Sample collection and processing}

Samples were collected in February, 2009, from five sites in the cave system (Fig 1). Sites 1 and 2 were collected from the Rotunda-Throne Room complex. Sites 3, 4, and 5 were collected from the Big Room complex which houses a small $(<2000)$ Myotis velifer colony from April to October every year. Three separate speleothems were selected for sampling from each site for a total of 15 samples. Site 1 samples were harvested from flow stone drapery and the other samples were taken from either stalactite or stalagmite formations (Table 1). These sites and formations were chosen after careful deliberation with park staff in an effort to sample actively dripping formations while avoiding areas of human impact from tourism.

Speleothems were sampled using the swab method as described in Ikner et al. (2007) with the following exceptions: sample tubes contained $4 \mathrm{~mL}$ of sterilized tap water and the area swabbed on each formation was $20 \mathrm{~cm}^{2}$. Three sterile cotton swabs were used per sample area. All samples were placed on ice and transported to the laboratory where samples were homogenized by vortexing for one $\mathrm{min}$ and then $1 \mathrm{~mL}$ was removed for sample plating and 3 $\mathrm{mL}$ was subjected to community DNA extraction for amplification of a portion of the $18 \mathrm{~S}$ subunit of the rRNA gene.

\section{Sample plating}

For each sample, one $\mathrm{mL}$ of the water suspension was removed immediately for sample plating on each of three different media, acidified potato dextrose agar (APDA) (Hong \& Pryor, 2004), weak acidified potato dextrose agar (WAPDA) (Hong \& Pryor, 2004), and a non-acidified low nutrient isolation medium (15.0 g Bacto-agar, 1.0 g yeast extract, $1.0 \mathrm{~L}$ tap water, $50 \mathrm{mg}$ L-1 each of streptomycin, penicillin, and ampicillin). These media were chosen to represent both nutrient rich and nutrient poor conditions and each selected for fungal growth either through low $\mathrm{pH}$ (acidified media) or addition of antibiotics to suppress bacteria. Samples were plated on each medium ( $0.1 \mathrm{~mL}$ volume) in triplicate and spread evenly across the surface using a bent glass rod and a plate turntable. Plates were incubated in the dark at room temperature $(\sim 25 \circ \mathrm{oC})$ for five days. After incubation, plates were examined for the presence of fungal colonies. Each individual colony was marked and the plates were reexamined every $48 \mathrm{~h}$ for 10 days or until counted fungal colonies started to coalesce. Exact colony counts of each MTU were not reported for the isolation procedures since multiple colonies could arise from spores or hyphal fragments from single fungal thalli.

\section{Isolation, spore induction, and identification}

Individual colonies from each plate, regardless of the original isolation medium, were subcultured onto new APDA plates to obtain pure cultures. Plates then were incubated at room temperature under fluorescent lighting for up to three months and scanned daily for contamination. Following subculturing, all isolates were grouped into morphological taxonomic units (MTU) based on colony morphology (e.g., color and shape, growth pattern, and production of pigmented exudates, etc.) and the production of spores. Plates that initially failed to sporulate were subjected to a series of different growth conditions (e.g. intense light, low nutrient medium) to further induce sporulation. All sporulating colonies were observed under the microscope and identified to the genus level based on spore morphology (Gilman, 1957; Ellis, 1971; Ellis, 1976; Barnett \& Hunter, 1987; St-Germain \& Summerbel, 1996; Watanabe, 2002). Non-sporulating colonies were also placed into MTUs based on colony morphology, but could not be placed to any specific genera.

\section{DNA extraction and PCR amplification}

Up to three members of every MTU recovered from every sample were randomly selected for DNA extraction and PCR amplification. In cases where there were three or fewer isolates from any given MTU from a single sample, all the isolates were subjected to DNA extraction and PCR amplification. Genomic DNA was extracted using the FastDNA kit (MP Biomedicals, LLC, Solon, Ohio, USA) as per manufacturer instructions. Extracted DNA was quantified using a NanoDrop 1000 Spectrophotometer (Thermo Fisher Scientific Inc., Wilmington, DE, USA), and then subjected to PCR amplification for the nuclear ribosomal internal transcribed spacer (ITS) bar-coding region using the forward primer ITS5 (GGA AGT AAA AGT CGT AAC AAG G) and the reverse primer ITS4 (TCC TCC GCT TAT TGA TAT GC) (White et al., 1990). Each 25 uL PCR reaction contained $0.08 \mathrm{uM}$ of each primer, 0.2 $\mathrm{mM}$ of each dNTP, $1 \mathrm{X}$ buffer (containing $10 \mathrm{mM}$ Tris$\mathrm{HCl}(\mathrm{pH} 8.8), 50 \mathrm{mM} \mathrm{KCl}$, and $0.08 \%$ Nonidet $\mathrm{P} 40$ ), $2.5 \mathrm{mM} \mathrm{MgCl}, 1 \mathrm{U}$ of Taq DNA polymerase (Fermentas Inc., Burlington, Ontario, Canada), and $0.8 \mathrm{ng}$ uL-1 genomic DNA. The amplification program was $95^{\circ} \mathrm{C}$ for five min, 34 cycles of $95^{\circ} \mathrm{C}$ for $40 \mathrm{sec}, 55^{\circ} \mathrm{C}$ for 40 sec, and $72^{\circ} \mathrm{C}$ for $1 \mathrm{~min}$, with a final extension step of $72^{\circ} \mathrm{C}$ for $10 \mathrm{~min}$.

\section{Identification of non-sporulating isolates and phylogenetic analysis}

Successfully amplified ITS regions were sequenced at the University of Arizona Genetics Core at the Arizona Research Laboratories. Individual sequences of nonsporulating MTUs were queried against the NCBI "nr" sequence database using the basic local alignment search tool (BLAST) for tentative identifications based on sequence similarity.

A tentative identification was assigned if $75 \%$ of the top 20 BLAST hits that referred to a named organism favored a particular genus identification. Assumed 


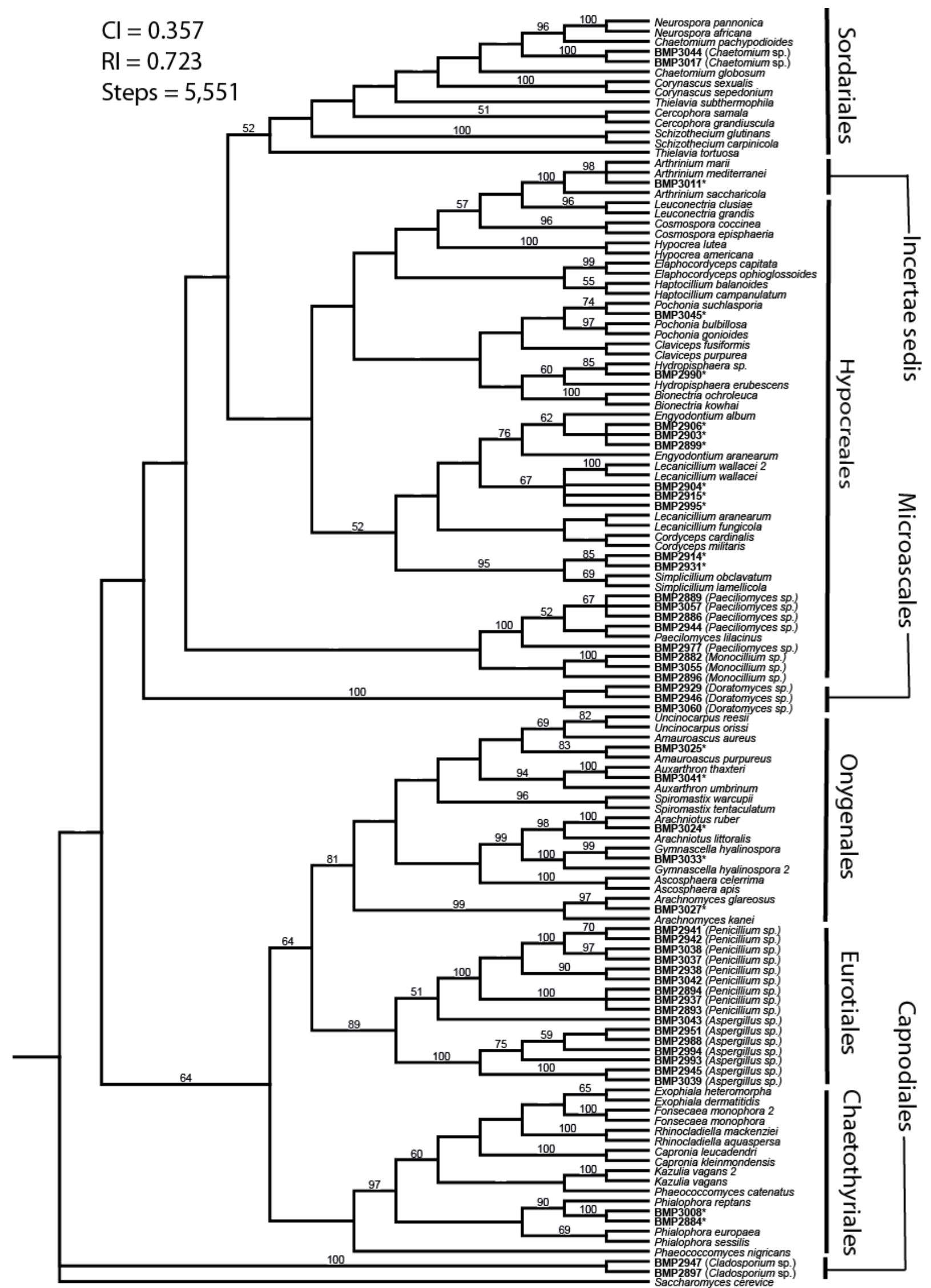

Fig. 2. Consensus tree from 27 most parsimonious reference trees for Ascomycota orders Hypocreales, Sordariales, Onygenales, Eurotiales and Chaetothyriales with recovered sporulating and non-sporulating taxa from Kartchner Caverns. Sporulating isolates are indicated by a BMP collection ID number followed by identified genus. Non-sporulating isolates are designated by a BMP collection ID number followed by an asterisk. 
closely related sister taxa were chosen from the top BLAST hits for each sequence based on BLAST similarity statistics and sister taxa positions in the BLAST distance tree view utility (Table 2). To support genus designation of all MTU's, tentatively identified MTUs were then examined within a phylogenetic context by placing them into a reference tree created for the taxonomic order that encompassed each of the tentatively identified MTUs. For each order, an ITS sequence matrix was created that included sequences from each target MTU and representative sequences from known species in each of the represented orders that included those MTUs compiled from NCBI and AFTOL databases. Resulting matrices were aligned using ClustalW v. 2.0.12 and edited using Mesquite v.2.72 (Thompson et al., 1994; Maddison \& Maddison, 2009). Manual adjustments to alignments were made using MacClade (Maddison \& Maddison, 1989). A heuristic parsimony search was conducted for each reference tree with included unidentified, nonsporulating taxa using PAUP v.4.0 beta (Swofford, 2002). Default parameters were used in the heuristic searches, except that sequence addition was set to random and each search was set to 1000 repetitions with the tree-bisection-reconnection (TBR) branch swapping algorithm. A full heuristic bootstrap search with 1000 random sequence additions and 1000 bootstrap replicates was conducted for each tree to obtain support values. These values were then mapped on to a majority rule consensus tree of the most parsimonious trees.

\section{MTU accumulation curve and projected MTU richness}

An analysis for the observed and projected MTU richness was conducted in the EstimateS software package v.8.2 (Colwell, 2005). Observed MTU richness was calculated as presence of observed MTUs across all 15 samples in the cave. This calculation was computed from 50 randomizations of the observed data to account for patchiness and to smooth out the plotted curve (Colwell et al., 2004). The projected

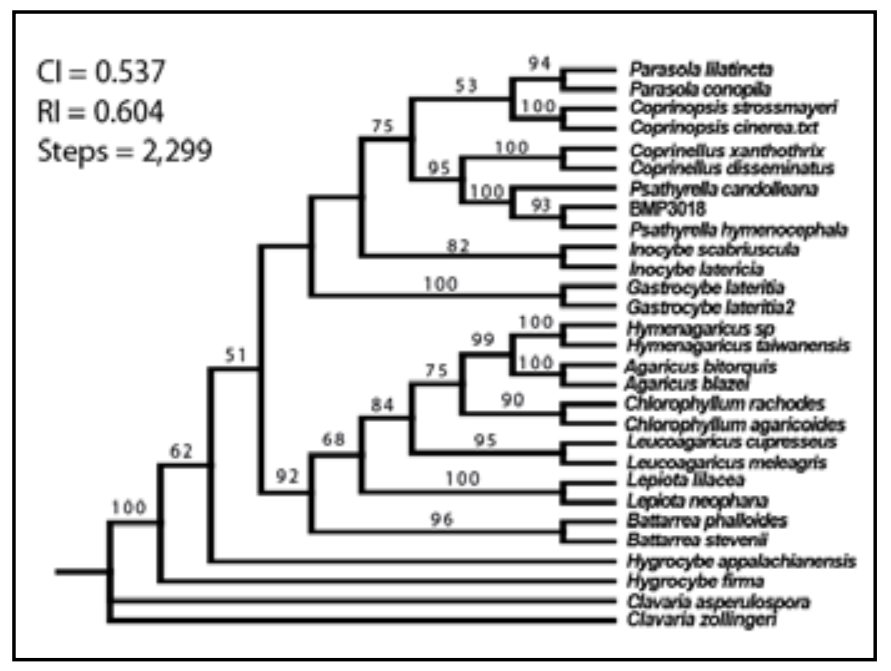

Fig. 3. Single most parsimonious reference tree for the Agaricales (Basidiomycota) with recovered non-sporulating taxon from Kartchner Caverns.
MTU richness was calculated using the Chao2 classic mean (Chao, 1984; 1987), chosen because it requires only presence-absence data and is more resistant to small sample numbers in calculating projected richness.

\section{DGGE community profiling}

Community DNA was extracted from the remaining $3 \mathrm{~mL}$ of swab suspension. The aqueous sample was centrifuged in $1 \mathrm{~mL}$ aliquots at $14,000 \mathrm{x}$ g for $10 \mathrm{~min}$ at $4^{\circ} \mathrm{C}$. The resulting pellet was then subjected to DNA extraction using the FastDNA Spinkit for Soil following standard manufacturer protocol (MP Biomedicals, LLC, Solon, Ohio, USA). The extracted community DNA was then pooled by sample and subjected to PCR amplification with the primers NS1 (White et al., 1990) and GCFung (May et al., 2001) under the same PCR conditions mentioned previously. Successful DGGEPCR reactions, with a product size of approximately $350 \mathrm{bp}$, were then quantified using a NanoDrop 1000 Spectrophotometer.

The DGGE analysis was carried out in a DCode Universal Mutation Detection System (Bio-Rad Laboratories, Inc., Hercules, CA). Acrylamide gels (7\%) were prepared with a 20 to $45 \%$ urea-formamide denaturing gradient according to the manufacturer's protocol. Twelve samples were loaded onto a DGGE gel at a time including a blank and two ladders. Multiple gels were run such that all samples could be compared on the same gel. Gels were run in triplicate to assure reproducibility. Gel lanes were loaded with $2500 \mathrm{ng}$ PCR product and then run at a voltage of $100 \mathrm{~V}$ for $30 \mathrm{~min}$ followed by $35 \mathrm{~V}$ for $18 \mathrm{~h}$ in $0.5 \mathrm{x}$ TAE buffer $(1 \times$ TAE $=40 \mathrm{mM}$ Tris acetate and $1 \mathrm{mM}$ EDTA) heated to $60^{\circ} \mathrm{C}$. The gel was stained with $2 \mathrm{x}$ SYBR Green I (Molecular Probes, Inc.) for $40 \mathrm{~min}$ and then visualized and imaged with UV fluorescence in an EpiChem3 imaging system (UVP, San Gabriel, CA). The resulting banding patterns were evaluated using Quantity One 4.6.9 software (BioRad Laboratories). The presence of a faint band was confirmed if the intensity of the band was $>5 \%$ of the intensity of the most intense band in the same lane, after subtraction of the background intensity to normalize peaks.

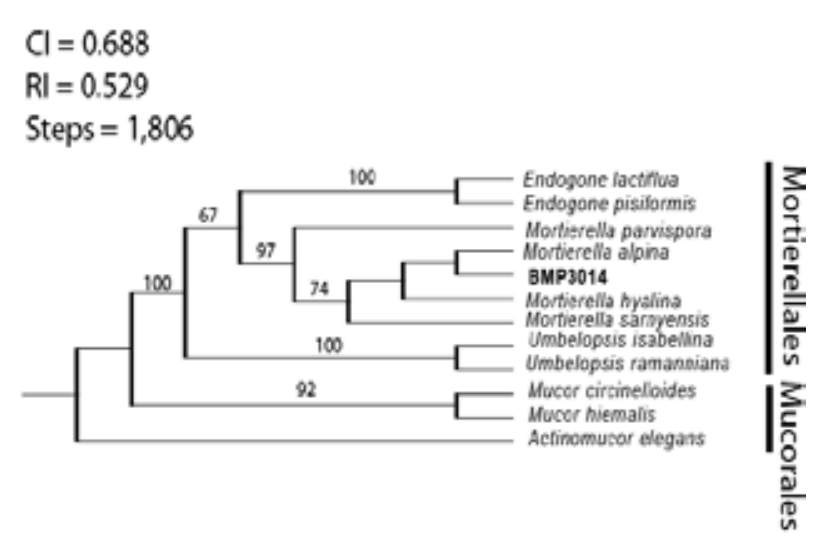

Fig. 4. Single most parsimonious reference tree for the Mortierellales (Mucoromycotina) with the recovered non-sporulating taxon from Kartchner Caverns. 


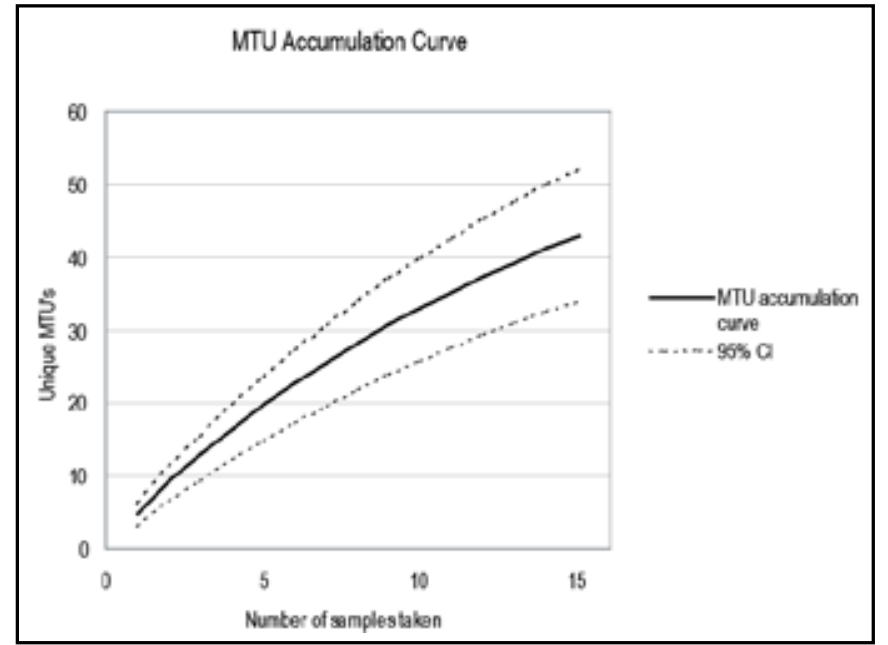

Fig. 5. An MTU accumulation curve for the speleothems sampled in this survey. The increasing slope of the curve suggests that sampling was not sufficient to capture the entire filamentous fungal MTU richness of the communities on speleothems in Kartchner.

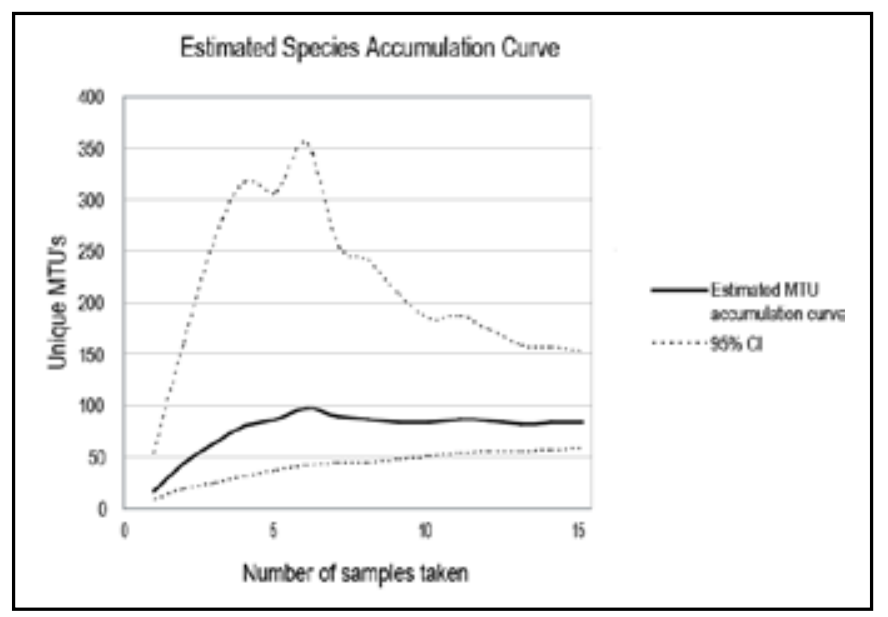

Fig. 6. A projected total filamentous fungal MTU richness curve for the speleothems in Kartchner Caverns. From this curve it appears that approximately half of the MTU richness was recovered in this survey.

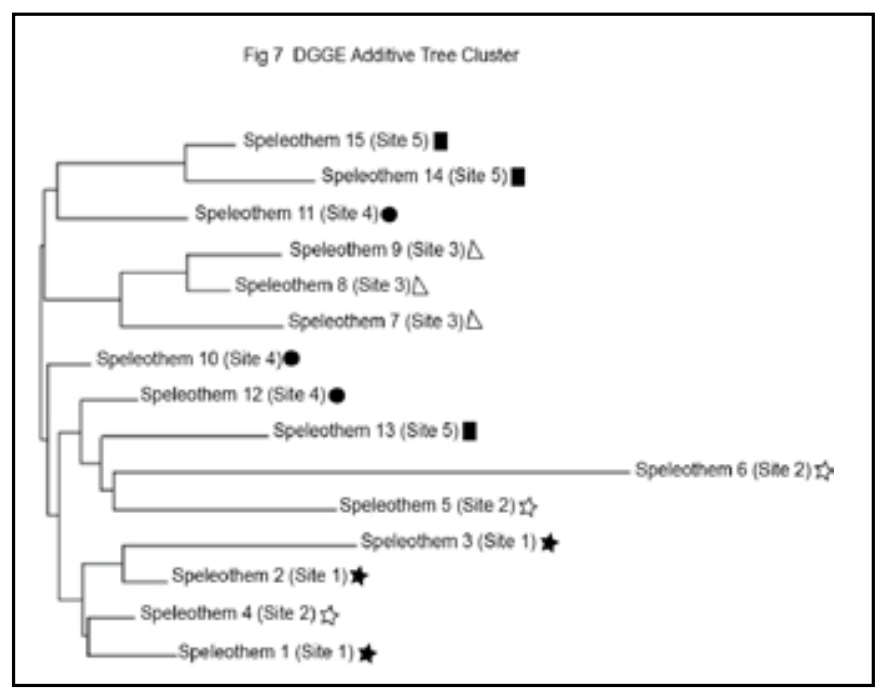

Fig. 7. The additive tree cluster analysis for the Dice's similarity coefficient matrices for DGGE profiles for speleothems sampled in Kartchner Caverns. Branch lengths represent distances between speleothems among all clusters.

\section{Comparisons among sample sites}

To examine if different sample sites varied in the number of recovered fungal taxa, the number of distinct MTUs and GTUs were compared across sampling sites using analysis of variance (ANOVA). All ANOVA tests were carried out using JMP v.7 software (SAS Institute Inc., Cary, NC, 1989-2007).

To examine similarities in DGGE bands among sampling sites, DGGE profile data were subjected to cluster analysis. Using the statistical analysis package SYSTAT 13 (Systat Software, Inc, Chicago IL, 2009), a similarity matrix for DGGE bands from each speleothem was constructed for a presence/absence dataset using Dice's binary similarity coefficients. The DGGE profiles for each speleothem were then clustered using an additive tree algorithm used to compare similarity data that uses branch lengths to represent similarity distances between objects (Sattath \& Tversky, 1977).

To examine the effects of sample site on community composition, DGGE profiles of each speleothem were analyzed using canonical correspondence analysis (CCA) using the program Canoco v. 4.5 (Biometris, Wageningen University, Netherlands, 1988-2010). CCA is widely used in community ecology applications and functions by finding axes of variation in data sets that maximize the relationship between explanatory variables or treatments (ter Braak, 1986; Palmer, 1993; Legendre \& Legendre, 1998). In this study, CCA eigenvalues represent the strength of the relationship between the DGGE banding profiles and the explanatory variables, and these are tested against a null hypothesis of no relationship using a permutation test (ter Braak $\&$ Wiertz, 1994). Specifically, CCA was used to look for an effect of site location or type of speleothem sampled on the DGGE profile from each speleothem.

\section{RESULTS}

Isolation, spore induction, and identification

Based upon colony morphology characteristics on APDA, a total of 53 morphologically distinct taxonomic units (MTU) out of 179 individuals were isolated from across the cave (Table 3). Following incubation on varied media under light, 32 of the isolated MTUs were induced to sporulate. Morphological examination of sporulating MTUs allowed identification of 7 distinct fungal genera. The most commonly isolated genera were Penicillium (9 distinct MTUs), Paecilomyces (5 distinct MTUs), Aspergillus (7 distinct MTUs), and Cladosporium (3 distinct MTUs).

\section{Sequence-based identification and phylogenetic analysis}

Among the 32 MTUs identified to genus by spore morphology, 23 were confirmed as distinct genetic taxonomic units (GTUs) by sequencing of the ITS region. A number of MTUs that were different based on colony color and size had ITS sequences that were identical. BLAST searches of each of the sporulating GTUs against NCBI databases confirmed that their genus identifications derived from morphological characterization were correct. Species designations were not given to isolates. 


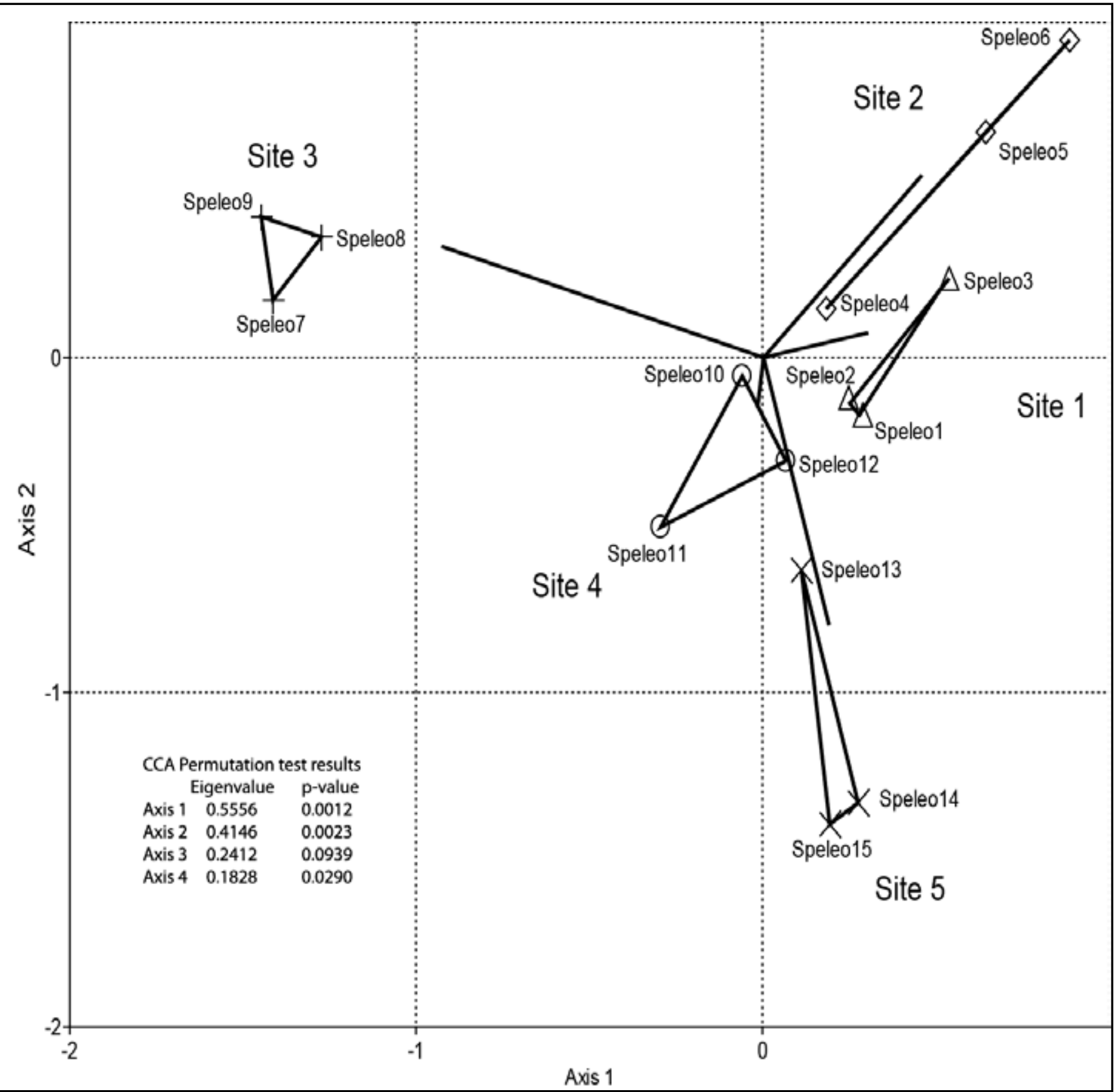

Fig. 8. CCA triplot showing the relationships between DGGE profile bands, the speleothems sampled, and the sample sites. Lines represent the sampling sites and the plotted symbols represent the individual speleothems.

Repeated attempts to induce sporulation of 21 of the recovered MTUs were not successful. Following BLAST searches against the NCBI databases, the 21 non-sporulating MTUs were resolved into 14 GTUs, and tentatively identified as members of 14 distinct fungal genera representing 4 orders of the Ascomycota (Chaetothyriales, Hypocreales, Onygenales, Sordariales, 12 genera), one order of the Basidiomycota (Agaricales, one genus), and one order of the subphylum Mucoromycotina (Mortierellales, one genus). Species designations were not given to isolates.

Both sporulating and non-sporulating MTUs were placed into reference sequence matrices, by fungal division, and including representative sister taxa for all tentative identifications. For ease of data presentation, the orders from the Ascomycota were combined into one dataset whereas the other orders were presented separately (Figs. 2-4). Combining both sporulation-based and DNA-based identifications, a total of 21 genera were represented (Table 3).

\section{MTU accumulation curve and projected MTU richness}

The MTU accumulation curve does not approach an asymptote, suggesting that the sampling effort employed was not large enough to capture the actual MTU richness of the speleothem surfaces (Fig. 5). It is estimated that approximately $51 \%$ of the actual MTU richness was recovered from the projected total MTU 
richness curve (Fig. 6). Similarly, when accumulation curves were constructed looking at the number of isolated individuals versus new MTUs, the curve did not reach an asymptote. Thus, our sampling effort would need to be greatly increased to saturate the fungal MTU accumulation curves for speleothems in Kartchner Caverns.

\section{DGGE community profiling}

DGGE banding patterns were found to be very reproducible across all speleothems and gels in terms of the number and position of particular bands although the relative intensities of some bands showed variation. A total of 29 different DGGE bands resulted from the processing of the profiles for all speleothems (Table 4). Speleothems 2 and 4 had the fewest bands, 5 and 4 respectively, and speleothems 3 and 6 had the highest number, 9 and 12 respectively.

\section{Comparisons among sample sites}

The four primary sporulating genera, along with Philaphora, Doratomyces and Lecanicillium, were the only genera found at more than one site across the cave. Site 2 contained the greatest number of recovered MTUs (21) and averaged 9.3 MTUs per sample (Table 3). However, there were no statistically significant differences among sites in terms of average number of MTUs recovered $(F(4,10)=1.5331, p=0.73)$. Site 5 contained the greatest richness of recovered genera (14) and averaged 7 distinct genera per sample. Similarly, there was no significant difference among sites in terms of in the average number of genera recovered $(F(4,10)=$ 1.6172, $\mathrm{p}=0.76$ ). Moreover, there was no significant difference in the number of recovered MTUs or number of genera per sample between samples taken across the cave (ANOVA; $F(1,13)=0.0321,0.0256 ; p=0.14,0.12)$.

The additive tree cluster analysis of the DGGE profiles created a stable site specific cluster for site 3 (speleothems 7, 8, and 9) (Fig. 7). The other speleothems did not create clusters segregated by sampling site. CCA analysis of the community DNA (DGGE profiles) shows a significant difference $(P=0.001)$ among the profiles generated for speleothems based on the collection site of the sample (Fig 8). The effect of cave section (with $M$. velifer or without $M$. velifer) where the sample sites were located was also significant $(\mathrm{P}=0.001)$, as was the type of speleothem (stalactite, stalagmite, or flowstone) the sample was taken from $(\mathrm{P}=0.010)$.

\section{DISCUSSION}

This study represents the first in a series to examine fungal diversity specifically from speleothem surfaces in Kartchner Caverns. Preliminary studies revealed that the fungal richness from individual speleothem surfaces was low, averaging 2-5 MTUs per speleothem (Vaughan et al., 2008). These early studies also found that the fungal communities were homogeneous, having the same taxa across sample sites. The current study revealed that the number of MTUs from each speleothem was higher, averaging 3-9 MTUs per speleothem. Moreover, when the MTUs from across sampling sites were examined in this study, a high degree of heterogeneity among speleothem fungal communities was revealed. This finding was supported by the DGGE community profiles, which demonstrated a significant effect of sampling site on profile band composition. Additionally, the MTU accumulation curve showed that only half of the projected number of MTUs were recovered indicating that the cave fungal community richness is even higher than what was recovered.

In this study, species identifications based upon BLAST results of ITS sequences were not made since ITS sequences do not have sufficient taxonomic resolution for many fungal groups (Chillali et al., 1998; Skouboe et al., 1999; Vialle et al., 2009). This may explain why the 53 MTUs defined based on colony color and size resolved into 43 GTUs based on 100\% ITS rDNA sequence similarity. Multiple genetic loci may need to be employed to assign a species designation with more confidence. The parsimony analysis of reference trees statistically supported most tentative genus identifications of both sporulating and non-sporulating MTUs. An exception was the isolate represented by BMP2915, a tentatively identified Lecanicillium in the Hypocreales by BLAST search, which had uncertain placement. BMP2915 formed a strongly supported clade with Lecanicillium wallaci, which in itself does not form a clade with other Lecanicillium species and is of uncertain taxonomic affiliation. However, there are a number of taxonomic synonymies within the Cordycipitaceae, which includes Lecanicillium, Engyodontium, and Simplicillium among others, and this might explain the unsupported taxonomy of some members of this group.

The genera represented in our sampling are similar to the genera found in other studies of cave systems (Rutherford \& Huang, 1994; Reeves et al., 2000; Grishkan et al., 2004; Nováková, 2009). For example, in Nováková's studies in Slovak Karst National Park, 73 genera were isolated, and most of the genera from the present study appear in Nováková's inventory. Commonly found genera included Penicillium, Aspergillus, Paecilomyces, and Lecanicillium, among others, throughout the cave. Similarly, Grishkan et al. (2004) found an abundance of Aspergillus spp. and heavily melanized fungi in their study site in Israel. The present study does not make species identifications, so direct comparisons to the species found in other studies cannot be made to infer ecological roles. However, these comparisons are useful to explore fungal richness from these environments using MTU designations.

In addition to culture-based work, culture-independent profiles for each formation were created using DGGE analysis of community $18 \mathrm{~S}$ rDNA amplicons. The primer set NS1/ GCFung is useful despite its inability to resolve species placements because of its high PCR efficiency and reproducibility across most fungal groups, resulting in robust profiles that can be used to discriminate between sampling sites (Duong et al., 2006; Hoshino \& Morimoto, 2008). There were generally fewer fungal DGGE bands per formation (4 to 12) in this study compared to a bacterial analysis of Kartchner speleothems which showed 31 to 36 bands per formation 
(Legatzki et al., in press). This difference may be due to the unequal power of the bacterial and fungal loci used for these analyses where the fungal bands likely represent OTUs resolved only to the Family or Order level. Similarly, many studies using DGGE to profile soil communities for fungi use primer sets for loci like ITS with a higher taxon resolution, possibly resulting in the greater number of bands per profile in these studies (Curlevski et al., 2010). However, it is also likely that the oligotrophic environment of the cave supports smaller assemblages of fungi than surface soils. The latter argument is supported by a recent DGGE analysis that showed 27 to $4118 \mathrm{~S}$ rDNA amplicon bands in a DGGE analysis of fungi in a Japanese rice patty fields. These patties would be considered nutrient rich in comparison to Kartchner Caverns (Hoshino \& Morimoto, 2008).

When comparing the cultured community on speleothem surfaces, there was no significant difference among sites in terms of number of MTUs or GTUs. Similarly, there was no significant difference between speleothems sampled from parts of the cave that are impacted or are unaffected by the $M$. velifer colony in terms of the number of taxa surveyed. The lack of statistical differences among sites and between different sides of the cave could be due to the rather large variation in the intra-site number of MTUs or GTUs recovered and the incomplete sample saturation for the culture library, possibly compromising inferences from these comparative statistics.

For the uncultured community the cluster analysis shows a trend for within site differences in OTU presence/absence. In the DGGE additive tree, clusters are formed that contain speleothems from multiple sites in the cave and from both sides of the cave. The cluster analyses suggest that there is a low degree of intra-site species specificity among the sampled sites based solely on distance measures of OTU presence and absence on the DGGE profiles. The CCA analysis of DGGE profiles shows a statistical significance for the effect of site location and further shows an effect of the presence or absence of $M$. velifer. Additional analyses also showed that there is an effect of the type of speleothem sampled on the observed profiles. Based on these data, two conclusions were derived. First, the fungal richness of speleothem surfaces is much greater than expected from our preliminary studies prior to the initiation of the MO project. Second, fungal community structure appears to be influenced by the site location of the speleothem.

In summary, the culture analysis of micro-fungi in this study highlights that there is a rich set of fungi found on speleothem surfaces in Kartchner Caverns. Future studies examining culturable fungal diversity from speleothem surfaces in Kartchner Caverns will expand sampling depth in an effort to saturate taxon representation. This will allow for better estimations of community homogeneity from speleothems thorough out the caverns. It has been estimated that only 2 to $5 \%$ of environmental fungi have been identified, likely due to an inability to culture most taxa (Hawksworth, 1991, 2001; O’Brien et al., 2005). For this reason, future studies in Kartchner Caverns will incorporate more culture independent methods of constructing fungal community identity such as environmental pyrosequencing, to detect unculturable taxa as well as the more easily accessible culturable taxa.

Table 1. Sample site information for the speleothems examined in this study. All formations were wet and actively dripping or being dripped upon. The Throne-Room Rotunda Complex is designated by TRR and the Big Room Complex is designated by BR.

\begin{tabular}{|c|c|c|c|c|}
\hline Formation number & Speleothem type & Color & Sampling site & Cave section \\
\hline Speleothem 1 & Flowstone & Light Brown & & \\
\hline Speleothem 2 & Flowstone & Light Brown & Site 1 & TRR \\
\hline Speleothem 3 & Flowstone & Light Brown & & \\
\hline Speleothem 4 & Stalactite & White & & \\
\hline Speleothem 5 & Stalagmite & White & Site 2 & TRR \\
\hline Speleothem 6 & Stalagmite & White & & \\
\hline Speleothem 7 & Stalactite & Light Brown & & \\
\hline Speleothem 8 & Stalactite & Light Brown & Site 3 & $\mathrm{BR}$ \\
\hline Speleothem 9 & Stalactite & Light Brown & & \\
\hline Speleothem 10 & Stalagmite & Red Brown & & \\
\hline Speleothem 11 & Stalactite & Cream & Site 4 & $\mathrm{BR}$ \\
\hline Speleothem 12 & Stalactite & Cream & & \\
\hline Speleothem 13 & Stalactite & Cream & & \\
\hline Speleothem 14 & Stalactite & Cream & Site 5 & $\mathrm{BR}$ \\
\hline Speleothem 15 & Stalactite & Cream & & \\
\hline
\end{tabular}


Table 2. Kartchner Caverns isolates used for phylogenetic placement of MTUs to genus. Included are the top BLAST hits for each sequence from NCBI.

\begin{tabular}{|c|c|c|c|c|c|}
\hline $\begin{array}{l}\text { Kartchner } \\
\text { Caverns } \\
\text { isolate } \\
\text { number }\end{array}$ & MTU designation & $\begin{array}{c}\text { NCBI } \\
\text { Accession for } \\
\text { Kartchner } \\
\text { Caverns } \\
\text { isolates }\end{array}$ & Top BLAST hit a & $\begin{array}{l}\text { \% Sequence } \\
\text { identity }\end{array}$ & $\begin{array}{c}\text { NCBI } \\
\text { Accession }\end{array}$ \\
\hline ВMP3025 & Amauroascus & HQ832952 & Amauroascus albicans & $88 \%$ & AJ271432 \\
\hline ВМР3024 & Arachniotus & HQ832953 & Gymnoascus ruber & $97 \%$ & AJ315839 \\
\hline BMP3027 & Arachnomyces & HQ832954 & Arachnomyces glareosus & $95 \%$ & AY624316 \\
\hline BMP3011 & Arthrinium & HQ832955 & Arthrinium phaeospermum & $99 \%$ & FJ462766 \\
\hline BMP2945 & Aspergillus 1 & HQ832956 & Aspergillus versicolor & $99 \%$ & EF652478 \\
\hline BMP2951 & Aspergillus 2 & HQ832957 & Aspergillus ustus & $99 \%$ & AY373873 \\
\hline BMP2988 & Aspergillus 3 & HQ832958 & Aspergillus ustus & $99 \%$ & DQ649067 \\
\hline BMP2993 & Aspergillus 4 & HQ832959 & Aspergillus ustus & $99 \%$ & EF652492 \\
\hline BMP2994 & Aspergillus 5 & HQ832960 & Aspergillus ustus & $99 \%$ & EF652492 \\
\hline ВМР3039 & Aspergillus 9 & HQ832961 & Aspergillus versicolor & $99 \%$ & FJ878625 \\
\hline ВMP3043 & Aspergillus W & HQ832962 & Aspergillus flavipes & $96 \%$ & GU566209 \\
\hline BMP3041 & Auxarthron 1, 2 & HQ832963 & Auxarthron thaxteri & $98 \%$ & AJ271571 \\
\hline BMP3044 & Chaetomium 1, 2 & HQ832964 & Chaetomium aureum & $85 \%$ & GU966501 \\
\hline BMP3017 & Chaetomium 3 & HQ832965 & Chaetomium sp. & $93 \%$ & EU750692 \\
\hline BMP2947 & Cladosporium 1 & HQ832966 & Cladosporium cladosporioides & $99 \%$ & EF577236 \\
\hline ВMP2897 & Cladosporium 2 & HQ832967 & Cladosporium cladosporioides & $99 \%$ & EF577236 \\
\hline ВMP2929 & Doratomyces 1 & HQ832968 & Doratomyces microsporus & $98 \%$ & GU566278 \\
\hline BMP2946 & Doratomyces 2 & HQ832969 & Doratomyces microsporus & $99 \%$ & FJ914687 \\
\hline BMP3060 & Doratomyces 3 & HQ832970 & Doratomyces microsporus & $99 \%$ & FJ914687 \\
\hline BMP2906 & Engyodontium 1 & HQ832971 & Engyodontium album & $99 \%$ & AB106650 \\
\hline BMP2903 & Engyodontium 2 & HQ832972 & Lecanicillium kalimantanense & $99 \%$ & AB360356 \\
\hline BMP2899 & Engyodontium 3 & HQ832973 & Engyodontium album & $99 \%$ & AB106650 \\
\hline ВMP3033 & Gymnascella & HQ832974 & Gymnascella hyalinospora & $99 \%$ & AY304513 \\
\hline BMP2990 & Hydropisphaera & HQ832975 & Acremonium persicinum & $99 \%$ & AB540575 \\
\hline BMP2904 & Lecanicillium 1 & HQ832976 & Lecanicillium kalimantanense & $98 \%$ & AB360356 \\
\hline BMP2915 & Lecanicillium 2 & HQ832977 & Lecanicillium kalimantanense & $98 \%$ & AB360356 \\
\hline BMP2995 & Lecanicillium 3 & HQ832978 & Lecanicillium kalimantanense & $98 \%$ & AB360356 \\
\hline BMP2882 & Monocillium 1 & HQ832979 & Acremonium persicinum & $97 \%$ & AB540575 \\
\hline BMP3055 & Monocillium 2 & HQ832980 & Acremonium persicinum & $97 \%$ & AB540575 \\
\hline BMP2896 & Monocillium 3 & HQ832981 & Acremonium furcatum & $98 \%$ & HQ637291 \\
\hline ВMP3014 & Mortierella & HQ832982 & Mortierella umbellata & $96 \%$ & AB476423 \\
\hline BMP2886 & Paecilomyces U & HQ832983 & Paecilomyces lilacinus & $99 \%$ & EU553286 \\
\hline BMP2889 & Paecilomyces 1 & HQ832984 & Paecilomyces lilacinus & $99 \%$ & EU553286 \\
\hline BMP2977 & Paecilomyces 2 & HQ832986 & Paecilomyces lilacinus & $96 \%$ & GQ229080 \\
\hline BMP2944 & Paecilomyces 3 & HQ832985 & Paecilomyces lilacinus & $99 \%$ & GQ229080 \\
\hline BMP3057 & Paecilomyces 4 & HQ832987 & Paecilomyces lilacinus & $96 \%$ & GQ229080 \\
\hline BMP2894 & Penicillium 1 & HQ832989 & Penicillium pinophilum & $99 \%$ & GQ22 1867 \\
\hline BMP2941 & Penicillium 2 & HQ832992 & Penicillium chrysogenum & $99 \%$ & AF034857 \\
\hline BMP2893 & Penicillium 2.8 & HQ832988 & Penicillium pinophilum & $99 \%$ & GU566216 \\
\hline BMP2938 & Penicillium 3 & HQ832991 & Penicillium griseofulvum & $99 \%$ & EU497951 \\
\hline BMP2942 & Penicillium 4 & HQ832993 & Penicillium crustosum & $100 \%$ & GU134895 \\
\hline BMP3037 & Penicillium 5 & HQ832994 & Penicillium polonicum & $99 \%$ & GU566221 \\
\hline ВMP3038 & Penicillium 6 & HQ832995 & Penicillium polonicum & $99 \%$ & GU566221 \\
\hline BMP3042 & Penicillium 9 & HQ832996 & Penicillium steckii & $100 \%$ & EF634431 \\
\hline BMP2937 & Penicillium 10 & HQ832990 & Penicillium pinophilum & $99 \%$ & GU566216 \\
\hline BMP3008 & Phialophora 1 & HQ832997 & Phialophora olivacea & $99 \%$ & AB190379 \\
\hline ВMP2884 & Phialophora 2 & HQ832998 & Phialophora olivacea & $99 \%$ & AB190379 \\
\hline BMP3045 & Pochonia & HQ832999 & Pochonia suchlasporia & $98 \%$ & FJ439582.2 \\
\hline ВMP3018 & Psathyrella & HQ833000 & Psathyrella candolleana & $98 \%$ & DQ389720 \\
\hline ВMP2914 & Simplicillum 1 & HQ833001 & Simplicillium lamellicola & $91 \%$ & AB2 14656 \\
\hline BMP2931 & Simplicillum 2 & HQ833002 & Simplicillium lamellicola & $91 \%$ & AB2 14656 \\
\hline
\end{tabular}

a Unidentified clones and environmental sequences were excluded from these searches 
Table 3. Filamentous fungi recovered from speleothem surfaces in Kartchner Caverns by sampling site (indicated by an X).

$\begin{array}{llllll}\text { MTU collection ID } & \text { SITE } 1 & \text { SITE } 2 & \text { SITE } 3 & \text { SITE } 4 & \text { SITE } 5\end{array}$

Amauroascus ${ }^{\mathrm{a}}$

Arthrinium ${ }^{a}$

Arachniotus $^{\text {a }}$

Arachnomyces $^{a}$

Aspergillus 1

Aspergillus 2

Aspergillus 3

Aspergillus 4

Aspergillus 5

Aspergillus 9

Aspergillus W

Auxarthron 1 a

Auxarthron 2 a

Chaetomium 1

Chaetomium 2

Chaetomium 3

Cladosporium 1

Cladosporium 2

Doratomyces 1

Doratomyces 2

Doratomyces 3

Engyodontium 1 a

Engyodontium 2 a

Engyodontium 3 a

Gymnascella ${ }^{\mathrm{a}}$

Hydropisphaera ${ }^{a}$

Lecanicillium $1^{\text {a }}$

Lecanicillium 2 a

Lecanicillium 3 a

Monocillium 1

Monocillium 2

Monocillium 3

Mortierella $1^{\text {a }}$

Paecilomyces 1

Paecilomyces 2

Paecilomyces 3

Paecilomyces 4

Paecilomyces U

Penicillium 1

Penicillium 2

Penicillium 2.8

Penicillium 3

Penicillium 4

Penicillium 5

Penicillium 6

Penicillium 9

Penicillium 10

Phialophora $1^{\text {a }}$

Phialophora $2^{\text {a }}$

Pochonia

Psathyrella ${ }^{a}$

Simplicillum $1^{\text {a }}$

Simplicillum $2^{\text {a }}$

$\begin{array}{llll}\text { SITE } 1 & \text { SITE } 2 & \text { SITE } 3 & \text { SITE } 4\end{array}$

SITE 5

(n)

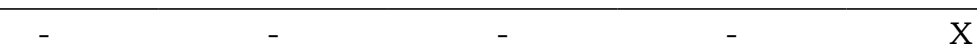

$\mathrm{X}$

$\mathrm{X}$

$\mathrm{X}$

X

\begin{tabular}{lcccccc}
\hline Average MTUs per sample & - & 3 & 9.3 & 4.7 & 3.7 & 7.7 \\
\hline Total MTUs per site & 53 & 8 & 22 & 11 & 12 & 19 \\
\hline
\end{tabular}

a. These genera were identified to genus based on ITS rDNA sequences and BLAST analysis.. 
Table 4. Sampled speleothems and their associated DGGE bands. Bands are represented by a number corresponding to their vertical position in the gel, with 1 melting in the lowest denaturant concentration and 29 in the highest.

\begin{tabular}{ll}
\hline Speleothem ID & DGGE Band present \\
\hline Speleothem 1 & $1,3,9,11,13$ \\
Speleothem 2 & $2,3,9,11,13$ \\
Speleothem 3 & $2,3,8,9,11,13,22,23$ \\
\hline Speleothem 4 & $3,9,11,13$ \\
Speleothem 5 & $8,9,11,13,19,21,22,28$ \\
Speleothem 6 & $\begin{array}{l}3,4,9,11,17,20,21,23,25, \\
\text { Speleothem } 7\end{array}$ \\
\hline Speleothem 8 & $6,10,11,13,15,24$ \\
Speleothem 9 & $6,9,11,12,13,15,24$ \\
\hline Speleothem 10 & $9,11,13$ \\
Speleothem 11 & $5,10,11,13$ \\
Speleothem 12 & $9,11,13,17$ \\
\hline Speleothem 13 & $9,10,11,13,17,27,28$ \\
Speleothem 14 & $\begin{array}{l}1,2,11,13,14,17,18 \\
\text { Speleothem } 15\end{array}$ \\
\hline
\end{tabular}

\section{ACKNOWLEDGEMENTS}

This work was supported in part by the National Science Foundation (NSF MCB-0604300) and the College of Agriculture and Life Sciences, University of Arizona. Additional thanks goes to Arizona State Parks and the dedicated members of the cave unit at Kartchner Caverns for their help and advice.

\section{REFERENCES}

Ajello L., Briceno-Maaz T., Campins H. \& Moore J., 1960 - Isolation of Histoplasma capsulatum from an oil bird (Steatornis caripensis) cave in Venezuela. Mycopathologia, 12: 199-206.

Barnett H.L. \& Hunter B.B., 1987 - Illustrated genera of imperfect fungi, fourth edition. Macmillan Publishing Company, New York, 218 p.

Barton H.A. \& Northup D.E., 2007 - Geomicrobiology in cave environments: past, current and future perspectives. Journal of Cave and Karst Studies, 69: 163-178.

Bastian F. \& Alabouvette C., 2009 - Lights and shadows on the conservation of a rock art cave: the case of Lascaux Cave. International Journal of Speleology, 38: 55-60.

Buecher R., 1999 - Microclimate study of Kartchner Caverns State Park, Arizona. Journal of Cave and Karst Studies, 61: 108-120.

Buecher D. \& Sidner R., 1999 - Bats of Kartchner Caverns State Park, Arizona. Journal of Cave and Karst Studies, 61:102-107.

Burford E.P., Fomina M. \& Gadd G.M., 2003a - Fungal involvement in bioweathering and biotransformation of rocks and minerals. Mineralogical Magazine, 67: 11271155.
Camassa M.M. \& Febroriello P., 2003 - Le foval della grotta Zinzulusa in Puglia (SE-Italia). Thalassia Salentina, Supplemento, 26: 207-218.

Cañaveras J.C., Cuezva S., Sanchez-Moral S., Lario J., Laiz L., Miguel Gonzalez J. \& Saiz-Jimenez C., 2005 - On the origin of fiber calcite crystals in moonmilk deposits. Naturwissenschaften, 93: 27-32.

Chao A., 1984 - Non-parametric estimation of the number of classes in a population. Scandinavian Journal of Statistics, 11: 265-270.

Chao A., 1987 - Estimating the population size for capturerecapture data with unequal catchability. Biometrics, 43: 783-791.

Chillali M., Idder-Ighili H. \& Guillaumin J.J., 1998 Variation in the ITS and IGS regions of ribosomal DNA among the biological species of European Armillaria. Mycological Research, 102: 533-540.

Colwell R.K., 2005 - EstimateS: Statistical estimation of species richness and shared species from samples: Version 8.2. User's Guide and application published at: http:// purl.oclc.org/estimates [accessed March 2, 2010].

Colwell R.K., Mao C.X. \& Chang J., 2004 - Interpolating, extrapolating, and comparing incidence-based species accumulation curves. Ecology, 85: 2717-2727.

Cuezva S., Sanchez-Moral S., Saiz-Jimenez C. \& Cañaveras J.C., 2009 - Microbial communities and associated mineral fabrics in Altamira cave, Spain. International Journal of Speleology, 38: 83-92.

Cunningham K.I., Northup D.E., Pollastro R.M., Wright W.G. \& LaRock E.J., 1995 - Bacteria, fungi and biokarst in Lechuguilla Cave, Carlsbad Caverns National Park, New Mexico. Environmental Geology, 25: 2-8.

Curlevski N.J.A., Xu Z.H., Anderson I.C. \& Cairney J.W.G., 2010 - Diversity of soil and rhizosphere fungi under Araucaria bidwillii (Bunya pine) at an Australian tropical montane rainforest site. Fungal Diversity, 40: 12-22.

Davis D.G., Palmer A.N. \& Palmer M.V., 1990 - Extraordinary subaqueous speleothems in Lechuguilla Cave, New Mexico. NSS Bulletin, 52: 70-86.

Duong L.M., Jeewon R., Lumyong S. \& Hyde K.D., 2006 $D G G E$ coupled with ribosomal DNA gene phylogenies reveal uncharacterized fungal phylotypes. Fungal Diversity, 23: 121-138.

Ehrlich H.L., 1998 - Geomicrobiology: its significance for geology. Earth-Science Reviews, 45: 45-60.

Ellis M.B., 1971 - Dematiaceous hyphomycetes: Kew, Surry, Commonwealth Agricultural Bureaux: 7-594.

Ellis M.B., 1976 - More Dematiaceous hyphomycetes. Kew, Surry, Commonwealth Agricultural Bureaux: 7-489.

Engel A., 2007 - Observations on the biodiversity of sulfidic karst habitats. Journal of Cave and Karst Studies, 69: 187-206.

Gadd G., 2004 - Mycotransformation of organic and inorganic substrates. Mycologist, 18: 60-70.

Gadd G.M. \& Sayer J.A., 2000 - Fungal transformations of metals and metalloids. In: Lovley D.R. (Ed.) - Environmental Microbe-Metal Interactions. Washington, DC: American Society for Microbiology: 237-256.

Garf C., 1999 - Hydrology of Kartchner Caverns State Park, Arizona. Journal of Cave and Karst Studies, 61: 59-67.

Gilman J.C., 1957 - A manual of soil fungi, second edition: Ames, Iowa: Iowa State College Press, p. 402.

Gorbushina A., 2007 - Life on the rocks. Environmental Microbiology, 9: 1613-1631.

Grishkan I., Nevo E. \& Wasser S., 2004 - Micromycetes from the Saline Arubotaim Cave: Mount Sedom, The Dead Sea Southwestern Shore. Israel Journal of Arid Environments, 57: 431-443. 
Hawksworth D.L., 1991 - The fungal dimension of biodiversity: magnitude, significance, and conservation. Mycological Research, 95: 641-655.

Hawksworth D.L., 2001 - The magnitude of fungal diversity: the 1.5 million species estimate revisited. Mycological Research, 105: 1422-1432.

Hill C., 1999 - Mineralogy of Kartchner Caverns State Park, Arizona. Journal of Cave and Karst Studies, 61: 73-78.

Hill C.A. \& Forti P., 1997 - Cave minerals of the World. Huntsville, Alabama: National Speleological Society, p. 463.

Hong G.S. \& Pryor B.M., 2004 - Development of selective media for the isolation and enumeration of Alternaria species from soil and plant debris. Canadian Journal of Microbiology, 50: 461-468.

Hoppert M., Flies C., Pohl W., Gunzl B. \& Schneider J., 2004 - Colonization strategies of lithobiontic microorganisms on carbonate rocks. Environmental Geology, 46: 421-428.

Hoshino Y.T. \& Morimoto S., 2008 - Comparison of 18 S rDNA primers for estimating fungal diversity in agricultural soils using polymerase chain reaction-denaturing gradient gel electrophoresis. Soil Science and Plant Nutrition, 54: 701710.

Hsu M.J. \& Agoramoorthy G., 2001 - Occurrence and diversity of thermophilous soil microfungi in forest and cave ecosystems of Taiwan. Fungal Diversity, 7: 27-33.

Ikner L.A., Toomey R.S., Nolan G., Neilson J.W., Pryor B.M. \& Maier R.M., 2007 - Cultural microbial diversity and the impact of tourism in Kartchner Caverns, Arizona. Microbial Ecology, 53: 30-42.

Jones D.S., Lyon E.H. \& Macalady J.L., 2008 Geomicrobiology of biovermiculations from the Frasassi Cave System, Italy. Journal of Cave and Karst Studies, 70: 78-93.

Landolt J.C., Stephenson S. L. \& Slay M.E., 2006 Dictyostelid cellular slime molds from caves. Journal of Cave and Karst Studies, 68: 22-26.

Legatzki A., Ortiz M., Neilson J.W., Doninguez S., Andersen G.L., Toomey R.S., Pryor B.M., Pierson L.S. III \& Maier R.M., 2010 - Bacterial and archaeal community structure of two adjacent calcite speleothems in Kartchner Caverns, Arizona, USA. Geomicrobiology Journal, in press.

Legendre P. \& Legendre L., 1998 - Numerical Ecology. Elsevier. Amsterdam: 870 p.

Lyon G.M., Bravo A.V., Espino A., Lindsley M.D., Gutierrez R.E., Rodriguez I., Corella A., Carrillo F., McNeil M.M., Warnock D.W. \& Hajjeh R.A., 2004 - Histoplasmosis associated with exploring a bat-inhabited cave in Costa Rica, 1998-1999. American Journal of Tropical Medicine and Hygiene, 70: 438-442.

Maddison W.P. \& Maddison D.R., 1989 - Interactive Analysis of Phylogeny and Character Evolution Using the Computer Program MacClade. Folia Primatologica., 53: 190-202.

Maddison W. P. \& Maddison D.R. 2009 - Mesquite: a modular system for evolutionary analysis: Version 2.72 http://mesquiteproject.org [accessed March 2, 2010].

May L.A., Smiley B. \& Schmidt M.G., 2001 - Comparative denaturing gradient gel electrophoresis analysis of fungal communities associated with whole plant corn silage. Canadian Journal of Microbiology, 47: 829-841.

Nagai K., Suzuki K. \& Okada G., 1998 - Studies on the distribution of alkalophilic and alkali-tolerant soil fungi II: Fungal flora in two limestone caves in Japan. Mycoscience, 39: 293-298.

Nováková A., 2009 - Microscopic fungi isolated from the Domica Cave system (Slovak Karst National Park, Slovakia), a review. International Journal of Speleology, 38: $71-82$.
O’Brien H.E., Parrent J.L., Jackson J.A., Moncalvo J.M. \& Vilgalys R., 2005 - Fungal community analysis by largescale sequencing of environmental samples. Applied and Environmental Microbiology, 71: 5544-5550.

Orpurthe P., 1964 - Microfungal flora of bat cave soils from eleuthera island, The Bahamas. Canadian Journal of Botany, 42: 1629-1633.

Palmer M.W., 1993 - Putting things in even better order: the advantages of canonical correspondence analysis. Ecology, 74: 2215-2230.

Reeves W., Jensen J. \& Ozier J., 2000 - New Faunal and Fungal Records from Caves in Georgia, USA. Journal of Cave and Karst Studies, 62: 169-179.

Rutherford J.M. \& Huang L.H., 1994 - A study of fungi of remote sediments in West Virginia caves and a comparison with reported species in the literature. NSS Bulletin, 56: 38-45.

Sattath S. \& Tversky A., 1977 - Additive similarity trees. Psychometrika, 42: 319-345.

St-Germain G. \& Summerbell R., 1996 - Identifying filamentous fungi: a clinical laboratory handbook. Belmont, California: Star Publishing Company: 288 p.

Skouboe P., Frisvad J.C. \& Taylor J.W., 1999 - Phylogenetic analysis of nucleotide sequences from the ITS region of terverticillate Penicillium species. Mycological Research, 103: $873-881$.

Swofford D.L., 2002 - PAUP* Phylogenetic Analysis Using Parsimony (*and Other Methods): Version 4. Sinauer Associates, Sunderland, Massachusetts.

ter Braak C.J.F., 1986 - Canonical correspondence analysis: a new eigenvector technique for multivariate direct gradient analysis. Ecology, 67: 1167-1179.

ter Braak C.J.F. \& Wiertz J., 1994 - On the statistical analysis of vegetation change: a wetland affected by water extraction and soil acidification. Journal of Vegetation Science, 5: 361-372.

Thompson J., Higgins D. \& Gibson T., 1994 - Clustal W: improving the sensitivity of multiple sequence alignment though sequence weighting, position-specific gap penalties and weight matrix choice. Nucleic Acids Research, 22: 4673-4680.

Tufts R. \& Tenen G., 1999 - Discovery and history of Kartchner Caverns, Arizona. Journal of Cave and Karst Studies, 61: 44-48.

Vaughan M.J., Pryor B.M., \& Maier R.M., 2008 - Fungal diversity in carbonate caves across diverse substrates. Ecological Society of America Annual Conference, Milwaukee, WI, August 2008.

Vialle A., Feau N., Allaire M., Didukh M., Martin F., Moncalvos J. \& Hamelin R., 2009 - Evaluation of mitochondrial genes as DNA barcode for Basidiomycota. Molecular Ecology Resources, 9: 99-113.

Watanabe T., 2002 - Pictorial atlas of soil and seed fungi: morphologies of cultured fungi and key to species, second edition: Boca Raton, Florida, 486 p.

Welbourn W.C., 1999 - Invertebrate cave fauna of Kartchner Caverns, Arizona. Journal of Cave and Karst Studies, 61: 93-101.

White T.J., Bruns T., Lee S. \& Taylor J.W., 1990 Amplification and direct sequencing of fungal ribosomal RNA genes for phylogenetics. In: Innis M. A., Gelfand D.H., Sninsky J.J. \& White T.J. (Eds.) - PCR Protocols: A Guide to Methods and Applications: Academic Press, Inc., New York: 315-322. 